\title{
Screening for propagation suitability in vitro of different Cyclamen species
}

\author{
Martina Seyring* \\ Department Plant Propagation \\ Leibniz-Institute of Vegetable and Ornamental Crops Großbeeren/Erfurt \\ Kuehnhaeuser Str. 101, D-99189 \\ Erfurt-Kuehnhausen, Germany \\ E-mail: seyring@erfurt.igzev.de \\ Aloma Ewald* \\ Department Plant Propagation \\ Leibniz-Institute of Vegetable and Ornamental Crops Großbeeren/Erfurt \\ Kuehnhaeuser Str. 101, D-99189 \\ Erfurt-Kuehnhausen, Germany \\ E-mail: ewald@erfurt.igzev.de \\ Anke Mueller \\ University of Applied Sciences Erfurt, Horticulture \\ Erfurt, Germany \\ Klaus-Thomas Haensch \\ Department Plant Propagation \\ Leibniz-Institute of Vegetable and Ornamental Crops Großbeeren/Erfurt \\ Erfurt-Kuehnhausen, Germany
}

Financial support: Ministries of Agriculture of the Federal Republic of Germany and the States of Brandenburg and Thueringen.

Keywords: propagation, shoot regeneration, somatic embryogenesis, species.

Abbreviations: 2,4-D: 2,4 dichlorophenoxyacetic acid
2iP: 6-( $\gamma \gamma$ - dimethylallylamino) purine
BAP: 6 benzylaminopurine
IES: Indolyle-3 acedic acid
NES: 1-naphtylacedic acid
SELS: somatic embryo-like structures

In the present study we examined the possibility of propagating different Cyclamen species (C. africanum Boiss. and Reut., C. cilicium Boiss. and Heldr., C. coum Mill., C. hederifolium Ait., C. persicum Mill., C. purpurascens Mill.) including some of their subspecies and cultivars in vitro using explants of adult plants. For this purpose two protocols have been applied to eleven genotypes combined with mostly four explant types (placentas with ovules, leaves, petioles and peduncles). The use of these protocols has given rise to either somatic embryo-like structures and/or adventitious shoots in all genotypes. This way it was possible to propagate each of the examined genotypes in vitro using explants of adult plants in a time less than one year. These results may be used in breeding and propagation of Cyclamen as an ornamental plant and as a medicinal plant.

The genus Cyclamen L. (Myrsinaceae) consists of more than 20 species, i.e. 22 species according to Grey-Wilson (2002) or 21 species according to Compton et al. (2004); and Yesson and Culham (2006). Propagation is exclusively performed by seeds. Only cultured varieties of Cyclamen persicum Mill. have so far had any commercial importance as an ornamental plant. Other species are largely neglected, due to their poor propagation qualities and other problems in cultivating them. Many species have nevertheless certain properties such as cold hardiness and high levels of resistance to various plant diseases that are potentially of great horticultural interest and value. The most cold hardy species are C. hederifolium Ait., C. coum Mill. and C. purpurascens Mill. Our own research has indicated that some wild species under investigation have higher levels of tolerance against Cyclamen wilt than the different $C$. persicum cultivars.

Other species of Cyclamen might be of interest for medical purposes (Çaliş et al. 1997a; Çaliş et al. 1997b; Speroni et al. 2007; Foubert et al. 2008; Quave et al. 2008).

Whereas studies have been conducted to elucidate the reproductive mechanisms in generative and vegetative

*Corresponding author 

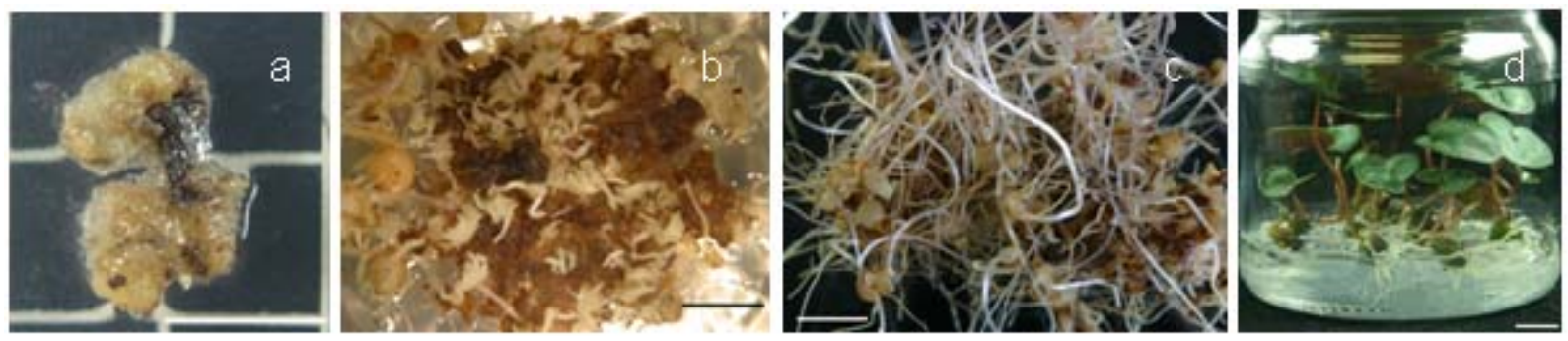

Figure 1. Regeneration of $\boldsymbol{C}$. coum magenta using peduncles applying protocol 1. (a) Induction of callus after eight weeks on medium with $9.05 \mu \mathrm{mol} \mathrm{I}^{-1}$ 2,4-dichlorophenoxyacetic acid (2.4-D) und $3.94 \mu \mathrm{mol} \mathrm{I}^{-1}$ 6-( $\mathrm{YY}$ - dimethylallylamino) purine (2iP); (b) Differentiation of somatic embryo-like structures (SELS) on growth regulator-free medium; (c) Development of SELS; (d) Regenerated plants. Bar. $10 \mathrm{~mm}(\mathrm{a}-\mathrm{d})$.

propagation of cultivated varieties of C. persicum Mill. and interspecific Cyclamen hybrids (Kiviharju et al. 1992; Ewald and Schwenkel, 1997; Schwenkel and Winkelmann, 1998; Ewald et al. 2000a; Ewald et al. 2000b; Karam and Al-Majathoub, 2000; Ishizaka, 2003; Rensing et al. 2005; Winkelmann and Serek, 2005; Reinhardt et al. 2008), little is known about the reproduction processes of most other species in this genus (Affre et al. 1995; Affre and Thomson, 1997a; Affre and Thomson, 1997b; Affre and Thomson, 1999). An efficient vegetative propagation of Cyclamen is possible only by using in vitro culture. Reports about this method are restricted to the wild species C. persicum (Karam and Al-Majathoub, 2000) and its cultivars (Hohe et al. 2000). This knowledge has been applied by Prange et al. (2008) for establishing the in vitro propagation of four other wild species of Cyclamen starting from juvenile explants. However one prerequisite for the propagation of quality tested plants is that explants from adult plants can be used. The aim of the present study was therefore to perform a screening for the possibility of propagating different wild species and subspecies of the genus Cyclamen and their cultivars in vitro using explants from adult plants.

\section{MATERIALS AND METHODS}

The study included eleven genotypes of the genus Cyclamen (different species, subspecies and cultivars, Table 1).

Explants were extracted from young leaves, petioles, flower buds and peduncles of adult plants from the greenhouse.

The leaves with petioles were disinfected for three minutes in a $0.8 \%$ silver nitrate solution and were rinsed three times for 5 min each time in sterile distilled water.

The peduncles and flower buds were immersed for $30 \mathrm{sec}$ in alcohol (70\%) before being disinfected for $20 \mathrm{~min}$ in a sodium hypochloride solution (3\% free chlorine). Following this, the plant material was rinsed three times for 5 min each time in autoclaved tap water.
Since the leaves had a maximum leaf blade width of $1 \mathrm{~cm}$, only a single explant could be extracted per leaf. Explants were extracted with a cork borer $(6 \mathrm{~mm})$ right beside the mid vein. Four segments (with a size of $5 \mathrm{~mm}$ each) were extracted from each petiole and peduncle. The flower buds, two to four days before start of anthesis, were exposed down to the ovary, and the central placenta with its ovules was vertically quartered. Due to the different growth patters of the original plants, however, not all types of explants from all genotypes could be subjected to exactly the same experiments at the same time. Between 4 and 36 explants per type of explant were analyzed. Each Petri dish contained four explants.

\section{Propagation using protocol 1}

Following Schwenkel and Winkelmann (1998), the primary culture (eight weeks) and the first sub-culture (four weeks) were applied on modified MS medium (Murashige and Skoog, 1962) at $9.05 \mu \mathrm{mol} \mathrm{l}^{-1} 2,4$ dichlorophenoxyacetic acid (2,4-D) and $3.94 \mu \mathrm{mol} \mathrm{l^{-1 }}$ 6-( $\gamma \gamma$ - dimethylallylamino) purine (2iP) and kept at $25^{\circ} \mathrm{C}$ in permanent darkness to induce and propagate calluses. In order to allow the differentiation and germination of somatic embryos, the callus was transferred to growth regulator-free MS medium and cultivated for 16 weeks at $23^{\circ} \mathrm{C}$ in permanent darkness. The further cultivation of the germinated somatic embryos into young plants was also performed on growth regulatorfree MS medium, but at $18^{\circ} \mathrm{C}$ under a $16 / 8 \mathrm{hrs}$ (light/dark) photoperiod with light supplied by white fluorescence lighting at an intensity of $46 \mu \mathrm{mol} \mathrm{s}{ }^{-1} \mathrm{~m}^{-2}$.

\section{Propagation using protocol 2}

The explants were established on modified N69 -medium (Nitsch and Nitsch, 1969) to which $6.66 \mu \mathrm{mol} \mathrm{l^{-1 }} 6$ benzylaminopurine (BAP), $5.71 \mu \mathrm{mol} \mathrm{l^{-1 }}$ Indolyle-3 acedic acid (IES) and $888.24 \mu \mathrm{mol} \mathrm{l}^{-1}$ of adenin were added, initially for six weeks at $20^{\circ} \mathrm{C}$ in permanent darkness, then for two weeks under a 16/8 hrs (light/dark) photoperiod with light supplied by white fluorescence lamps at an intensity of $46 \mu \mathrm{mol} \mathrm{s}^{-1} \mathrm{~m}^{-2}$. Following this, the explants were transferred for eight weeks on to $\mathrm{N} 69$ with $4.44 \mu \mathrm{mol}$ 


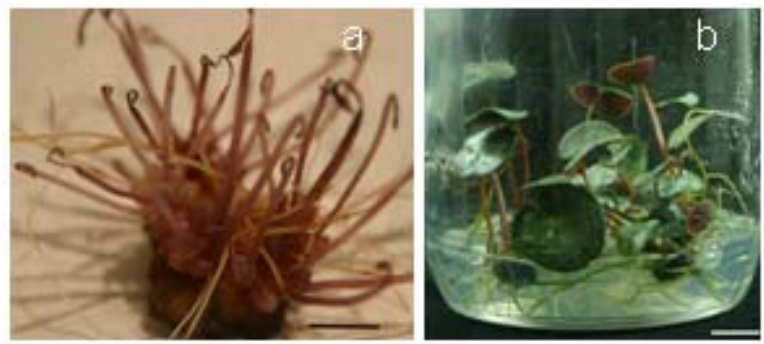

Figure 2. Regeneration of $C$. purpurascens on medium with 9.05 $\mu \mathrm{mol} \mathrm{I}^{-1}$ 2.4-D und $3.94 \mu \mathrm{mol} \mathrm{I}^{-1} 2 \mathrm{iP}$ using protocol 1 . (a) Formation of shoots on petioles; (b) Young plants in vitro on growth regulator-free medium. Bar. $10 \mathrm{~mm}(\mathrm{a}, \mathrm{b})$.

$\mathrm{l}^{-1} \mathrm{BAP}$ and $5.71 \mu \mathrm{mol} \mathrm{l}^{-1}$ IES. The N69 medium contained $10.74 \mu \mathrm{mol} \mathrm{l}^{-1} 1$-naphtylacedic acid (NES) to induce root formation.

\section{RESULTS}

\section{Regeneration using protocol 1}

In a space of eight to 12 weeks, callus had developed in all types of explants of all genotypes. The proportion of explants that had developed callus often exceeded $80 \%$. Only the petioles of $C$. hederifolium Ait. ssp. confusum (50\%) and the leaf explants of C. cilicium (20\%) fell short of this mark. Callus development was delayed in the leaf explants. C. coum magenta and C. purpurascens showed the most pronounced callus development in all explants, the explants being nearly totally covered in calluses.

After a period of three to seven months, structures began to differentiate depending on the genotype and type of explant (Table 1). Some structures appeared as shoots, whereas others resembled somatic embryos. Because no histological examination has been done the latter structures are designated as somatic embryo-like structures (SELS). The proportion of explants producing SELS hovered between 0 and $50 \%$ with only $C$. persicum pink developing only callus. After a period of seven months, different levels of developing SELS were observed (Table 1). Petiole explants of $C$. cilicium first grew large numbers of SELS, some of which began to develop while the SELS on the peduncle explants of $C$. africanum failed to develop further and eventually died.

SELS could be successfully induced in all types of explants of C. coum magenta (Figure 1). Leaf explants had the lowest proportion of explants with SELS (10\%) while placenta explants had the highest (30\%). With all genotypes with the exception of C. africanum SELS developed into plantlets.

Young plants had already developed after 10 months after beginning the culture except $C$. cilicium in which this process lasted longer.
C. coum magenta - with a total of 462 developing SELS in 11 explants after seven-months - produced the best result (Table 1). Out of 307 developing plantlets, which were transferred again to a growth regulator-free medium and cultivated in 16/8 hrs (light/dark) photoperiod, 89.6\% grew into fully transplantable young plants. 135 plants were adapted to greenhouse conditions. Only 3\% expressed an aberrant phenotype (autotetraploid).

The regenerants from protocol 1 of $C$. africanum petioles and all other regenerants of $C$. purpurascens with the exception of the placenta explants (Figure 2a) were classified as shoots (Table 1). The shoots were partly vitrified and initially showed signs of an abnormal growth. Further cultivation on growth regulator-free medium, however, produced rooted young plants (Figure $2 b$ ). These were phenotypically similar to the plants that had developed from SELS (Figure 1d).

\section{Regeneration using protocol 2}

After two months of cultivation, shoot formation could be induced in seven of the 11 genotypes (Table 2). The proportion of different types of explants with shoot formation fluctuated between 0 and $75 \%$. In addition to well-developed shoots, there were also some deformities and single leaves (Figure 3a to Figure 3d). Shoot formation was successfully induced in all types of explants of $C$. africanum, while $C$. cilicium and the three types of $C$. coum showed no reaction. In contrast to the results of protocol 1 , all explants of C. coum magenta eventually died. The highest numbers of normally developed shoots (after seven months) were observed in C. africanum, C. hederifolium ssp. confusum and C. purpurascens with 44,40 and 20 shoots respectively.

Root formation was observed in shoots that had been transferred to N 69 medium with $10.74 \mu \mathrm{mol} \mathrm{l}^{-1} \mathrm{NES}$. After five weeks, rooting rates in excess of $50 \%$ had been established in C. purpurascens (93\%), C. persicum (83.3\%), C. africanum (61.4\%) and C. hederifolium cv. 'Rosenteppich' (55.6\%) while C. hederifolium ssp. confusum lagged behind at only $15 \%$. In line with the rooting patterns of the different varieties, between one and six roots were developed per shoot.

Young plants had already developed after eight months after beginning the culture.

\section{DISCUSSION}

The previous knowledge concerning the in vitro propagation of Cyclamen is restricted to the species C. persicum (Karam and Al-Majathoub, 2000) and its cultivars. A comprehensive survey has been supplied for the latter by Winkelmann et al. (2000). Wild species of this genus possess a great potential for the improvement of Cyclamen as an ornamental plant and as a medicinal plant. For its use it is necessary to establish in vitro propagation 

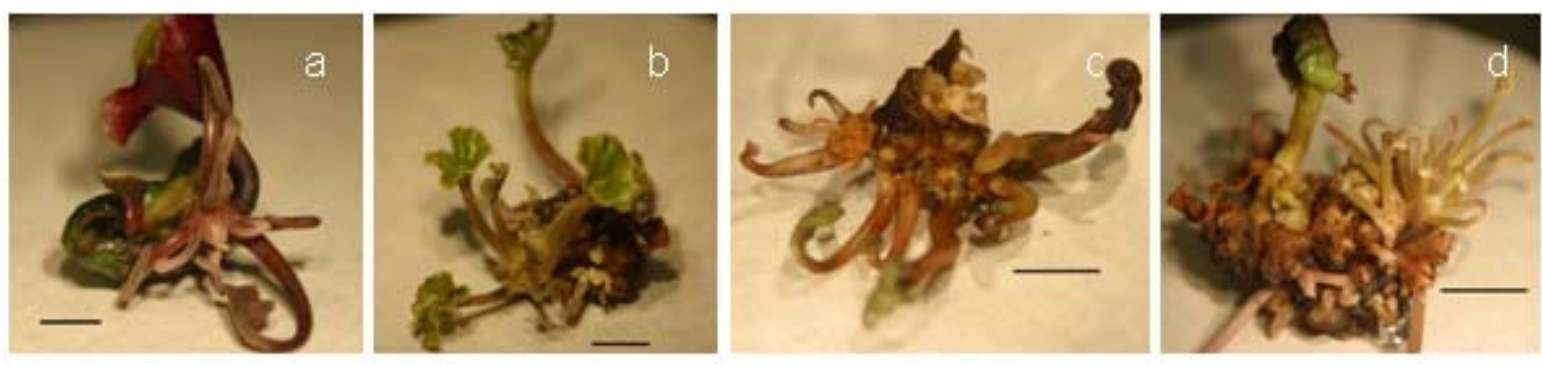

Figure 3. Formation of shoots in different Cyclamen species using protocol 2 after 14 weeks (cultivation for six weeks on $\mathrm{N}$ 69medium (N69) with $6.66 \mu \mathrm{mol} \mathrm{I}^{-1} 6$ Benzylaminopurine (BAP), $5.71 \mu \mathrm{mol} \mathrm{^{-1 }}$ Indolyle-3 acedic acid (IES), $888.24 \mu \mathrm{mol} \mathrm{I^{-1 }}$ Adenin followed by eight weeks on N 69 with $4.44 \mu \mathrm{mol} \mathrm{I}^{-1}$ BAP and $5.71 \mu \mathrm{mol} \mathrm{I}^{-1}$ IES using leaves (a-c) and peduncles (d). (a) $C$. purpurascens. (b) C. africanum. (c) C. hederifolium ssp. confusum. (d) C. persicum. Bar $10 \mathrm{~mm}$ (a-d).

methods. Therefore the experience with the in vitro propagation of $C$. persicum has been applied by Prange et al. (2008) to four other wild species of Cyclamen using explants of juvenile plants, i.e. cotyledons, tubers and roots of very young sterile seedlings. However one prerequisite for the use of in vitro propagation for large scale propagation as well as in the breeding process is that it is possible to use explants which are available after the plants have been tested for appearance, health, or technological traits. Until now there are no scientific reports about the regeneration of wild species of Cyclamen starting from explants disposable after quality tests. Therefore in the present report we examined the possibility of propagating different wild species and subspecies of the genus Cyclamen and their cultivars in vitro using explants of adult plants. For this purpose two protocols, which have been successfully used in the propagation of $C$. Persicum, have been applied to eleven genotypes combined with mostly four explant types. The intention of this study was to establish a comprehensive survey about the regeneration responses in the genus Cyclamen using a high number of treatment combinations. This was only possible by tolerating relative small sample sizes in some combinations and by performing the experiment without replications because of biological reasons. This special statistical approach allows to get such a survey (Baetz et al. 1982) but prevents to make differences between single treatments statistically evident. This must be considered when special treatments will be compared.

Protocol 1 has been reported by Schwenkel and Winkelmann (1998) to be suitable for the induction of somatic embryogenesis in isolated ovules of C. persicum. The application of this protocol to the genotypes examined in the present study resulted in most of the treatment combinations in the formation of structures which resembled somatic embryos (Table 1), i.e. bipolar structures as they have been defined by Haccius (1978) and as they have been examined in C. persicum by Wicart et al. (1984). They are designated in this study as SELS because the clarification of their nature needs histological examinations, which has not been the intention of the present study.
Furthermore the application of protocol 1 gave rise to shoots in some treatment combinations (Table 1).

Applying protocol 2 resulted only in the formation of shoots but not SELS. Differentiation of shoots has been observed in seven genotypes (Table 2). The genotypes $C$. cilicium, C. coum, C. coum ssp. coum and C. coum magenta did not form shoots.

The period necessary for the in vitro propagation using protocol 1 was in most genotypes 10 months and using protocol 2 about eight months after beginning the culture until to the formation of young plantlets. The use of protocol 1 and / or protocol 2 has given rise to either SELS or shoots in all the genotypes. This way it was possible to propagate each of the examined genotypes in vitro using explants of adult plants in a time less than one year. This is of practical importance because such a method could be integrated into the breeding process of Cyclamen. Single plants of the examined genotypes which have been assessed for their quality traits can now be cloned for their further use in programs for cross breeding or inter-specific hybridisation. Seed propagation would always lead to a strong segregation of traits in the descendent plants in these genotypes. Another advantage would be to use such in vitro propagation methods for the large scale propagation of Cyclamen as an ornamental plant and as a medicinal plant.

\section{REFERENCES}

AFFRE, Laurence; THOMSON, John D. and DEBUSSCHE, Max. The reproductive biology of the mediterranean endemic Cyclamen balearicum Willk. (Primulaceae). Botanical Journal of the Linnean Society, August 1995, vol. 118, no. 4, p. 309-330.

AFFRE, Laurence and THOMSON, John D. Variation in the population genetic structure of two Cyclamen species on the island of Corsica. Heredity, February 1997a, vol. 78, no. 2, p. 205-214.

AFFRE, Laurence and THOMSON, John D. Population genetic structure and levels of inbreeding depression in the 
Mediterranean island endemic Cyclamen creticum (Primulaceae). Biological Journal of the Linnean Society, April 1997b, vol. 60, no. 4, p. 527-549.

AFFRE, Laurence and THOMSON, John D. Variation in self-fertility, inbreeding depression and levels of inbreeding in four Cyclamen species. Journal of Evolutionary Biology, January 1999, vol. 12, no. 1, p. 113-122.

BAETZ, Gerd; DOERFEL, Hannelore; FUCHS, Armin and THOMAS, Erhard. Einführung in die Methodik des Feldversuchs. Berlin; VEB Deutscher Landwirtschaftsverlag, 1982. 327p. ISBN 3-33-100125-2.

ÇALIŞ, Ihsan; SATANA, Mesut Ersan; YÜRÜKER, Aysen; KELICAN, Pelin; DEMIRDAMAR, Rümeysa; ALACAM, Ruhi; TANKER, Nevin; RÜEGGER, Heinz and STICHER, Otto. Triterpene saponins from Cyclamen mirabile and their biological activities. Journal of Natural Products, March 1997a, vol. 60, no. 3, p. 315-318.

ÇALIŞ, Ihsan; YÜRÜKER, Aysen; TANKER, Nevin; WRIGhT, Antonny D. and STICHER, Otto. Triterpene saponins from Cyclamen coum var. coum. Planta Medica, April 1997b, vol. 63, no. 2, p. 166-170.

COMPTON, James A.; CLENNETT, J. Chris B. and CULHAM, Alastair. Nomenclature in the dock. Overclassification leads to instability: a case study in the horticulturally important genus Cyclamen (Myrsinaceae). Botanical Journal of the Linnean Society, November 2004, vol. 146, no. 3, p. 339-349.

EWALD, Aloma; ORLICZ-LUTHARDT, Anna; WINKELMANN, Traud and SCHWENKEL, Hans-Georg. Interspecific hybrids of Cyclamen persicum Mill. x C. purpurascens Mill: propagation, somaclonal variation, resistence to Fusarium wilt and suitability as an outdoor crop. Acta Horticulturae, 2000a, vol. 508, p. 309-310.

EWALD, Aloma; SCHWENKEL, Hans-Georg; LEPPER, Lothar and LIPPOLD, Rico. Sexual reproduction of interspecific hybrids between Cyclamen persicum Mill. and Cyclamen purpurascens Mill. Gartenbauwissenschaft, 2000b, vol. 65, no. 4, p. 162-169.

EWALD, Aloma and SCHWENKEL, Hans-Georg. Fertilization and seed formation of Cyclamen persicum Mill. Basic and applied aspects of seed biology. In: Proceedings of the Fifth International Workshop on Seeds, Reading. Kluwer Academic Publishers, 1997, p. 113-118.

FOUBERT, K.; THEUNIS, M.; APERS, S.; VLIETINCK, A.J. and PIETERS, L. Chemistry, distribution and biological activities of 13, 28-epoxy-oleanane saponins from the plant families myrsinaceae and primulaceae. Current Organic Chemistry, May 2008, vol. 12, no. 8, p. 629-642.
GREY-WILSON, Christopher. Cyclamen a guide for gardener, horticulturists and botanists. New edition; Batsford, London, 2002. 192 p. ISBN 9780881923865.

HACCIUS, Barbara. Question of unicellular origin of non zygotic embryos in callus cultures. Phytomorphology, March 1978, vol. 28, no. 1, p. 74-81.

HOHE, Annette; PUESCHEL, Anke-Kathrin and SCHWENKEL, Hans-Georg and WINKELMANN, Traud. Somatic embryogenesis in Cyclamen persicum Mill. Research Trends, 2000, vol. 2, no. 1, p. 51-62.

ISHIZAKA, H. Cytogenetic studies in Cyclamen persicum, C. graecum (Primulaceae) and their hybrids. Plant Systematics and Evolution, June 2003, vol. 239, no. 1-2, p. $1-14$.

KARAM, Nabila S. and AL-MAJATHOUB, Mohannad. In vitro shoot regeneration from mature tissue of wild Cyclamen persicum Mill. Scientia Horticulturae, December 2000, vol. 86, no. 4, p. 323-333.

KIVIHARJU, Elina; TOUMINEN, Ulla and TÖRMÄLÄ, Timo. The effect of explant material on somatic embryogenesis of Cyclamen persicum Mill. Plant Cell Tissue and Organ Culture, February 1992, vol. 28, no. 2, p. 187-194.

MURASHIGE, Toshio and SKOOG, Folke. A revised medium for rapid growth and bioassays with tobacco tissue cultures. Physiologia Plantarum, July 1962, vol. 15, no. 3, p. 473-497.

NITSCH, J.P. and NITSCH, C. Haploid plants from pollen grains. Science, January 1969, vol. 163, no. 3862, p. 85-89.

PRANGE, Anika Nadja Sabine; SEREK, Margrethe and WINKELMANN, Traud. Vegetative propagation of different Cyclamen species via adventitious shoot formation from seedling tissue. Propagation of Ornamental Plants, December 2008, vol. 8, no. 4, p. 204-209.

QUAVE, Cassandra L.; PLANO, Lisa R.W.; PANTUSO, Traci and BENNETT, Bradley C. Effects of extracts from Italian medicinal plants on planctonic growth, biofilm formation and adherence of methicillin-resistant Staphyllococcus aureus. Journal of Ethnopharmacology, August 2008, vol. 118, no. 3, p. 418-428.

REINHARDT, Sandra; EWALD, Aloma and HELLWIG, Frank. The correlation between ovule quality parameters and the seed yield at Cyclamen persicum Mill. Journal of Applied Botany and Food Quality, 2008, vol. 82, no. 1, p. 76-82.

RENSING, Stefan A.; LANG, Daniel; SCHUMANN, Eik; RESKI, Ralf and HOHE, Annette. EST sequencing from embryogenetic Cyclamen persicum cell cultures identifies a high proportion of transcripts homologous to plant genes 
involved in somatic embryogenesis. Journal of Plant Growth Regulation, June 2005, vol. 24, no. 2, p. 102-115.

SCHWENKEL, Hans-Georg and WINKELMANN, Traud. Plant regeneration via somatic embryogenesis from ovules of Cyclamen persicum Mill. Plant Tissue Culture and Biotechnology, March 1998, vol. 4, no. 1, p. 28-34.

SPERONI, E.; CERVELLATI, R.; COSTA, S.; DALL'ACQUA, S.; GUERRA, M.C.; PANIZZOLO, C.; UTAN, A. and INNOCENTI, G. Analgesic and antiinflammatory activity of Cyclamen repandum S. et S. Phytotherapy Research, July 2007, vol. 21, no. 7, p. 684689.

WICART, G.; MOURAS, A. and LUTZ, A. Histological study of organogenesis and embryogenesis in Cyclamen persicum Mill. tissue cultures: evidence for a single organogenetic pattern. Protoplasma, October 1984, vol. 119, no. 3, p. 159-167.

WINKELMANN, Traud and SEREK, Margrethe. Genotypic differences in callus formation and regeneration of somatic embryos in Cyclamen persicum Mill. Euphytica, July 2005, vol. 144, no. 1-2, p. 109-117.

YESSON, Chris and CULHAM, Alastair. A phyloclimatic study of Cyclamen. BMC Evolutionary Biology, September 2006, vol. 6, p. 72. 


\section{APPENDIX}

\section{TABLES}

Table 1. Regeneration of eleven Cyclamen-genotypes using protocol 1.

\begin{tabular}{|c|c|c|c|c|c|c|}
\hline \multirow[t]{2}{*}{$\begin{array}{c}\text { Genotype / Source of } \\
\text { explants }\end{array}$} & \multirow[t]{2}{*}{$\begin{array}{l}\text { Number of } \\
\text { explants }\end{array}$} & \multirow[t]{2}{*}{$\begin{array}{c}\text { Number of } \\
\text { sterile explants }\end{array}$} & \multirow[t]{2}{*}{$\begin{array}{l}\text { Start of } \\
\text { differentiation } \\
\text { after months }\end{array}$} & \multicolumn{2}{|c|}{$\begin{array}{c}\text { Explants with somatic } \\
\text { embryo-like structures } \\
\text { or shoots* }\end{array}$} & \multirow[t]{2}{*}{$\begin{array}{l}\text { Number of plantlets } \\
\text { after } 7 \text { months }\end{array}$} \\
\hline & & & & $\%$ & total & \\
\hline \multicolumn{7}{|l|}{ C. africanum } \\
\hline Placenta & 8 & 8 & 0 & 0 & & 0 \\
\hline Peduncle & 8 & 4 & 3 & 50.0 & 2 & 0 \\
\hline Leaf & 8 & 7 & 0 & 0 & & 0 \\
\hline Petiole & 20 & 16 & 7 & $12.5^{\star}$ & 2 & $2^{*}$ \\
\hline \multicolumn{7}{|l|}{ C. cilicium } \\
\hline Leaf & 8 & 4 & 0 & 0 & & 0 \\
\hline Petiole & 20 & 20 & 6 & 15.0 & 3 & 1 \\
\hline \multicolumn{7}{|l|}{ C. coum } \\
\hline Placenta & 36 & 24 & 3 & 4.2 & 1 & 8 \\
\hline Peduncle & 36 & 20 & 0 & 0 & & 0 \\
\hline Leaf & 8 & 6 & 0 & 0 & & 0 \\
\hline Petiole & 28 & 19 & 6 & 15.8 & 3 & 3 \\
\hline \multicolumn{7}{|l|}{ C. coum ssp. coum } \\
\hline Leaf & 20 & 7 & 0 & 0 & & 0 \\
\hline Petiole & 24 & 20 & 6 & 5.0 & 1 & 3 \\
\hline \multicolumn{7}{|l|}{ C. coum magenta } \\
\hline Placenta & 20 & 20 & 3 & 30.0 & 6 & 249 \\
\hline Peduncle & 20 & 12 & 3 & 25.0 & 2 & 200 \\
\hline Leaf & 20 & 10 & 6 & 20.0 & 2 & 10 \\
\hline Petiole & 24 & 20 & 3 & 10.0 & 2 & 3 \\
\hline $\begin{array}{l}\text { C. hederifolium ssp } \\
\text { confusum }\end{array}$ & & & & & & \\
\hline
\end{tabular}


Seyring, M. et al.

\begin{tabular}{|c|c|c|c|c|c|c|}
\hline Placenta & 4 & 4 & 0 & 0 & & 0 \\
\hline Peduncle & 4 & 4 & 0 & 0 & & 0 \\
\hline Leaf & 4 & 4 & 6 & 25.0 & 1 & 1 \\
\hline Petiole & 16 & 14 & 6 & 14.3 & 2 & 8 \\
\hline \multicolumn{7}{|c|}{$\begin{array}{l}\text { C. hederifolium cv. } \\
\text { 'Perlenteppich' }\end{array}$} \\
\hline Placenta & 20 & 11 & 0 & 0 & & 0 \\
\hline Peduncle & 20 & 8 & 0 & 0 & & 0 \\
\hline Leaf & 16 & 7 & 0 & 0 & & 0 \\
\hline Petiole & 20 & 16 & 3 & 12.5 & 2 & 2 \\
\hline \multicolumn{7}{|c|}{$\begin{array}{l}\text { C. hederifolium cv. } \\
\text { 'Rosenteppich' }\end{array}$} \\
\hline Placenta & 20 & 10 & 0 & 0 & & 0 \\
\hline Peduncle & 20 & 7 & 7 & 42.9 & 3 & 3 \\
\hline Leaf & 16 & 12 & 0 & 0 & & 0 \\
\hline Petiole & 20 & 20 & 0 & 0 & & 0 \\
\hline \multicolumn{7}{|c|}{ C. persicum } \\
\hline Placenta & 20 & 16 & 3 & 12.5 & 2 & 10 \\
\hline Peduncle & 20 & 4 & 3 & 50.0 & 2 & 8 \\
\hline Leaf & 4 & 4 & 0 & 0 & & 0 \\
\hline Petiole & 16 & 16 & 0 & 0 & & 0 \\
\hline \multicolumn{7}{|c|}{ C. persicum pink } \\
\hline Leaf & 4 & 4 & 0 & 0 & & 0 \\
\hline Petiole & 16 & 15 & 0 & 0 & & 0 \\
\hline \multicolumn{7}{|c|}{ C. purpurascens } \\
\hline Placenta & 20 & 15 & 3 & 6.7 & 1 & 16 \\
\hline Peduncle & 20 & 20 & $3^{*}$ & $20.0^{*}$ & 4 & $13^{*}$ \\
\hline Leaf & 12 & 12 & $6^{*}$ & $25.0^{*}$ & 3 & $50 *$ \\
\hline Petiole & 20 & 20 & $3^{*}$ & $25.0^{*}$ & 4 & $71^{*}$ \\
\hline
\end{tabular}

* Regenerants were classified as shoot formation 
Table 2. Regeneration of eleven Cyclamen-genotypes using protocol 2.

\begin{tabular}{|c|c|c|c|c|c|c|}
\hline \multirow[t]{2}{*}{$\begin{array}{c}\text { Genotype / Source of } \\
\text { explants }\end{array}$} & \multirow[t]{2}{*}{$\begin{array}{l}\text { Number of } \\
\text { explants }\end{array}$} & \multirow[t]{2}{*}{$\begin{array}{l}\text { Number of } \\
\text { sterile explants }\end{array}$} & \multirow{2}{*}{$\begin{array}{l}\text { Start of shoot } \\
\text { regeneration } \\
\text { after months }\end{array}$} & \multicolumn{2}{|c|}{$\begin{array}{l}\text { Explants with } \\
\text { shoots }\end{array}$} & \multirow[t]{2}{*}{$\begin{array}{c}\text { Number of shoots after } \\
7 \text { months }\end{array}$} \\
\hline & & & & $\%$ & total & \\
\hline \multicolumn{7}{|l|}{ C. africanum } \\
\hline Placenta & 20 & 12 & 2 & 8.3 & 1 & 0 \\
\hline Peduncle & 20 & 16 & 2 & 6.3 & 1 & 0 \\
\hline Leaf & 4 & 4 & 2 & 75.0 & 3 & 28 \\
\hline Petiole & 16 & 16 & 2 & 18.8 & 3 & 16 \\
\hline \multicolumn{7}{|l|}{ C. cilicium } \\
\hline Leaf & 16 & 14 & 0 & 0 & & 0 \\
\hline Petiole & 20 & 20 & 0 & 0 & & 0 \\
\hline \multicolumn{7}{|l|}{ C. coum } \\
\hline Placenta & 20 & 8 & 0 & 0 & & 0 \\
\hline Peduncle & 20 & 16 & 0 & 0 & & 0 \\
\hline \multicolumn{7}{|l|}{ C. coum ssp. coum } \\
\hline Leaf & 16 & 8 & 0 & 0 & & 0 \\
\hline Petiole & 20 & 19 & 0 & 0 & & 0 \\
\hline \multicolumn{7}{|l|}{ C. coum magenta } \\
\hline Placenta & 20 & 12 & 0 & 0 & & 0 \\
\hline Peduncle & 32 & 12 & 0 & 0 & & 0 \\
\hline Leaf & 8 & 3 & 0 & 0 & & 0 \\
\hline Petiole & 20 & 20 & 0 & 0 & & 0 \\
\hline \multicolumn{7}{|l|}{$\begin{array}{l}\text { C. hederifolium ssp. } \\
\text { confusum }\end{array}$} \\
\hline Placenta & 28 & 20 & 0 & 0 & & 0 \\
\hline Peduncle & 28 & 16 & 0 & 0 & & 0 \\
\hline Leaf & 12 & 5 & 2 & 40.0 & 2 & 3 \\
\hline Petiole & 20 & 19 & 2 & 36.8 & 7 & 37 \\
\hline $\begin{array}{l}\text { C. hederifolium cv. } \\
\text { 'Perlenteppich' }\end{array}$ & & & & & & \\
\hline
\end{tabular}


Seyring, M. et al.

\begin{tabular}{|c|c|c|c|c|c|c|}
\hline Placenta & 20 & 15 & 0 & 0 & & 0 \\
\hline Peduncle & 20 & 12 & 0 & 0 & & 0 \\
\hline Leaf & 8 & 4 & 2 & 25.0 & 1 & 2 \\
\hline Petiole & 20 & 20 & 2 & 5.0 & 1 & 0 \\
\hline \multicolumn{7}{|c|}{$\begin{array}{l}\text { C. hederifolium cv. } \\
\text { 'Rosenteppich' }\end{array}$} \\
\hline Placenta & 16 & 16 & 0 & 0 & & 0 \\
\hline Peduncle & 16 & 16 & 2 & 12.5 & 2 & 2 \\
\hline Leaf & 12 & 12 & 2 & 8.3 & 1 & 3 \\
\hline Petiole & 20 & 16 & 2 & 6.3 & 1 & 4 \\
\hline \multicolumn{7}{|c|}{ C. persicum } \\
\hline Placenta & 20 & 12 & 0 & 0 & & 0 \\
\hline Peduncle & 20 & 16 & 2 & 18.8 & 3 & 2 \\
\hline Leaf & 4 & 4 & 2 & 25.0 & 1 & 10 \\
\hline Petiole & 16 & 14 & 2 & 7.1 & 1 & 0 \\
\hline \multicolumn{7}{|c|}{ C. persicum pink } \\
\hline Placenta & 20 & 8 & 2 & 50.0 & 4 & 5 \\
\hline Peduncle & 20 & 20 & 2 & 45.0 & 9 & 9 \\
\hline Leaf & 4 & 4 & 2 & 25.0 & 1 & 0 \\
\hline Petiole & 12 & 12 & 0 & 0 & & 0 \\
\hline \multicolumn{7}{|c|}{ C. purpurascens } \\
\hline Placenta & 20 & 4 & 0 & 0 & & 0 \\
\hline Peduncle & 20 & 20 & 2 & 20.0 & 4 & 3 \\
\hline Leaf & 8 & 8 & 2 & 50.0 & 4 & 13 \\
\hline Petiole & 20 & 19 & 2 & 5.3 & 1 & 7 \\
\hline
\end{tabular}

